\title{
FUNNEL PARADOX OF INNOVATION STRATEGIES IN POLISH INDUSTRIAL ENTERPRISES. DOES LESS INNOVATION MEAN BETTER RESULTS?
}

The main purpose of this article is to assess the effects of innovation strategies applied in Polish industrial enterprises. Innovation strategies were based on a model defined by the simultaneous imposition of three criteria: the place of the innovation's creation (in-house or outside), the type of activity in terms of its continuity (continuous or occasional activity) and the innovation's utilisation (own use or sale). As a result, eight different variants of innovation strategy were created which allow for conducting an empirical verification procedure. The effects of innovation strategy were evaluated by the following criteria: the average number of created innovation, the impact on achieving competitive advantage and the most common result of applied innovation strategy. The test sample covered the period 2012-2014 and a group of medium and large Polish enterprises belonging to low, medium and high-tech industries. As a result of quantitative research, 84 responses were obtained. The main finding of this research is that the most represented variant of strategy is the individual innovator who also has the highest impact on achieving competitive advantage (4.625/5) and an above average number of created innovations (9/8). The key finding, in a broader sense, is the lack of correlation between the number of created innovations and the achieved competitive advantage (correlation coefficient 0.18). These phenomena, called innovation funnel paradox, were examined in detail and explained on the basis of literature and research findings.

Keywords: innovation, strategy, innovation strategy, effects, model, industry, company

DOI: $10.15611 /$ aoe.2019.1.15

\section{INTRODUCTION}

Innovation should be seen as one of the key dimensions of the functioning and development of an organization (Kaplan, Norton 1993, pp. 67-70). In particular, the key goal of innovation strategy is to ensure the long-term survival of a company and the growth of its competitiveness by creating revenue streams based on delivery value to customers. Therefore, one of the organization's main tasks is the choice of appropriate innovation projects in the context of the adaptation of its activities to the degree of competitiveness, development of technology and market conditions (Pomykalski 2001, pp. 17, 24, 77).

\footnotetext{
* Department of Organization Theory and Management, Poznań University of Economics.
} 
However, there is still insufficient knowledge about the dependencies influencing the efficiency innovation strategy. For instance, Christensen and Raynor (2008, p. 49) claim that there is no correlation between the level of a company`s engaged resources and the innovation outcome. Furthermore, they note that with the increase in the number of innovations, leading companies strengthen their position in the industry, but in terms of implementing ground-breaking innovations, compared to young companies, they are conservative and not very effective (Christensen, Raynor 2008, pp. 49-50). Paraphrasing, there are the phenomena of quality over quantity when referring to innovation strategy outcome. So does this mean that less innovation can obtain better results?

In this respect the main purpose of this article is to assess the effects of the innovation strategies applied in Polish industrial enterprises. Innovation strategies are defined by a model framework consisting of three simultaneously imposed criteria: the place of the innovation's creation, the type of activity in terms of continuity, and the innovation's utilisation. As a result, eight different variants of innovation strategy were created and this set the basis for further empirical verification.

This procedure was founded on five research questions:

1) What is the most and the least common innovation strategy within Polish industrial companies?

2) What are the main effects of each of the eight variants of innovation strategy within Polish industrial companies?

3) What is the average number of created innovations of each innovation strategy within Polish industrial companies?

4) Is there a correlation between the applied innovation strategy, industry and the achieved competitive advantage within Polish industrial companies?

5) Is there a correlation between the number of created innovations and the achieved competitive advantage within Polish industrial companies?

These research questions were verified on a test sample covering 20122014 in a group of medium and large Polish enterprises belonging to six branches of low, medium and high-tech industries.

The above defined goal contributed to the division of this paper into several chapters. The first part introduces the main theoretical perspectives of innovation strategies. This is followed by a description of the three criteria defining the boundary conditions and the framework of the innovation strategies' model. Next, we present the research results regarding the effects of the applied innovation strategies in Polish industrial enterprises. Finally we sum up with the conclusions. 


\section{THEORETICAL STARTING POINTS}

\subsection{Innovation strategies - main theoretical approaches}

Innovation can be described as the transformation of resources, as well as intangibles like information, knowledge and ideas, in order to build and sustain competitive advantage, and overall it constitutes an essential part of company strategy (Karlsson, Tavassoli 2016, p. 1484). Thus innovation can be treated as one of the most important factors of a company's development due to its dual role as both the source of change, raising uncertainty, and as a key resource of a firm shaping its competitive potential (Tidd, Bessant, Pavitt 2005, p. 111). The dilemma of whether to innovate or not can be particularly important in today's competitive environment, where leading companies can rarely maintain their competitive edge when facing technology or market change (Bower, Christensen 1995). Most companies cannot engage in creating all possible innovation types, mainly due to scarce resources (Karlsson, Tavassoli 2016, p. 1485). From the decision-makers perspective, innovation can be treated as the following dilemma: how in a recurrent and efficient way company's resources can be used in a rapidly changing, unpredictable and discontinuous environment? The answer to this question is revealed in a literature overview.

Innovation is, of course, a very complex and multidimensional approach. There is a large body of studies of the organizational determinants of innovativeness (Materia, Pascucci, Dries 2015, pp. 251-255), external determinants of innovativeness (Beers, Zand 2014, Laursen, Salter 2006), as well as the effects of innovation for companies and industries, and also the macroeconomic scope of factors on a regional or national level (Tavassoli 2014). Another perspective to consider is the relation between different theories and innovation performance (Ezzia', Jarboui 2016, pp. 15-16). The authors indicated the industrial approach (the relationship between the industry structure, the achieved position and the applied innovation strategy), the Chicago School (advantage is gained by the utilisation of individual skills and team composition), the resource-based view (innovation success is developed by the use of skills and strategic resources), the agency theory (the emphasis is on conflicts of interest represented by different opportunistic stakeholders and its influence on innovation performance). The next approach is the transaction cost theory (the view of innovation performance by making decisions on whether to do it through the market or within the hierarchy), the strategic approach (decision-makers can leverage 
innovative performance), the stewardship theory (maximizing agent interest but in accordance with the organization's goals) and the cognitive theory (innovation performance depends on leaders skills and their efficiency in the context of corporate governance).

Based on these different theories, several innovation strategies concepts can be distinguished (Drucker 2004, pp. 239-290, Whittington 1994):

- rationalist, with I. Ansoff as its main advocate, claiming that innovation should be treated as a formal and planned path of development that must take into account, and more importantly cope with, the complexity of a multidimensional set of interacting variables. In this approach it is crucial to accommodate the long-term growth perspective with operational activity also in terms of competitive actions, to ensure the company's capacity to react to a changing future, as well as provide coherence in goals with corresponding procedures and routines in a functionally specialized organization. One of the concepts from this perspective are technological paths (Dodgson 1989).

- incremental, supported by H. Mintzberg, seeing innovation strategy as the continuous adaptation to a complex environment as there is an insufficient level of knowledge and prediction capability to ensure the successful comprehension of everyday operations taking into account future changes. To foster this approach there is the need to explore the implications of different development paths and create a readiness to change strategy when new circumstances appear, emphasize the meaning of informal communication, gather information from different sources as well as support a culture of discussion and scepticism. The concept that embodies this approach is of dynamic capabilities (Teece 2007).

- position, with P. Drucker as main exponent, according to this perspective relations between entities in a competitive environment such as other companies within industry, suppliers and customers, are most important. The result of a firm's activity is dependent on introducing innovation corresponding to customer needs that will allow to discount their investment and will not be duplicated by competitors. P. Drucker distinguishes six innovation strategies defined according to: different market position, demand level, competitor`s threat of market acquisition and innovation imitation, and company's key resources including its technological capabilities and product type.

Except for the above-mentioned research perspectives, in literature there are many, more detailed and specific, concepts such as business process reengineering (Hammer, Champy 1993) and the open innovation model 
(Chesbrough 2004). However despite all of these propositions there is lack of a comprehensive and complex model that synthesizes the above presented approaches to a company's innovation strategy.

\subsection{Variants of innovation strategies - the model approach}

The basic assumption of this model is that a company's relationships with the entities in its competitive environment are created in order to realize innovative activity according to the organization's objectives and its competitive potential. Although accepting that each innovation project can be realized based on different assumptions and resources configuration, the presented model aims at grasping the main innovation strategy of a company. Therefore it was crucial to consider two opposing sets of criteria: 1) methodological, focusing on providing versatility and readability of the model that determine its utility and applicability; 2) substantive, relating to emphasizing the broad variety of different configurations of the purposes and conditions referring to the individual innovative behaviour of the organization.

As a result of the above-mentioned assumptions, three dimensions determining the shape of a company's innovative strategy were selected: place of innovation's creation (in-house or outside), type of activity in terms of its continuity (continuous or occasional activity) and innovation utilisation (own use or sale). As a consequence of the imposition of the above defined dimensions, a matrix consisting of eight different variants of innovation strategy was established. Those innovation strategy types are: buyers, collectors, individual innovators, occasional innovators, brokers, guerrillas, sellers and casual sellers (see Figure 1 and Table 1).

The first dimension is the place of innovation's creation. Companies, in order to ensure the efficiency of the operation, form relationships with other entities. This also applies to innovative activity. The main reason to outsource part of its key activities is striving to reduce transaction costs (Niemczyk 2004, pp. 60-61). Besides, other incentives to start cooperation relate to the division of labour and specialization of activities, access to technology, markets and know-how, and sharing the risk in the project. On the other hand, there are several negative effects of collaboration on innovative projects such as knowledge spillovers, strategic drift, unfavourable diversification, cost of cooperation and relationship management, lowering efficiency and product quality, cultural differences and conflicts (Tidd, Bessant, Pavitt 2005, p. 292). Most companies, 


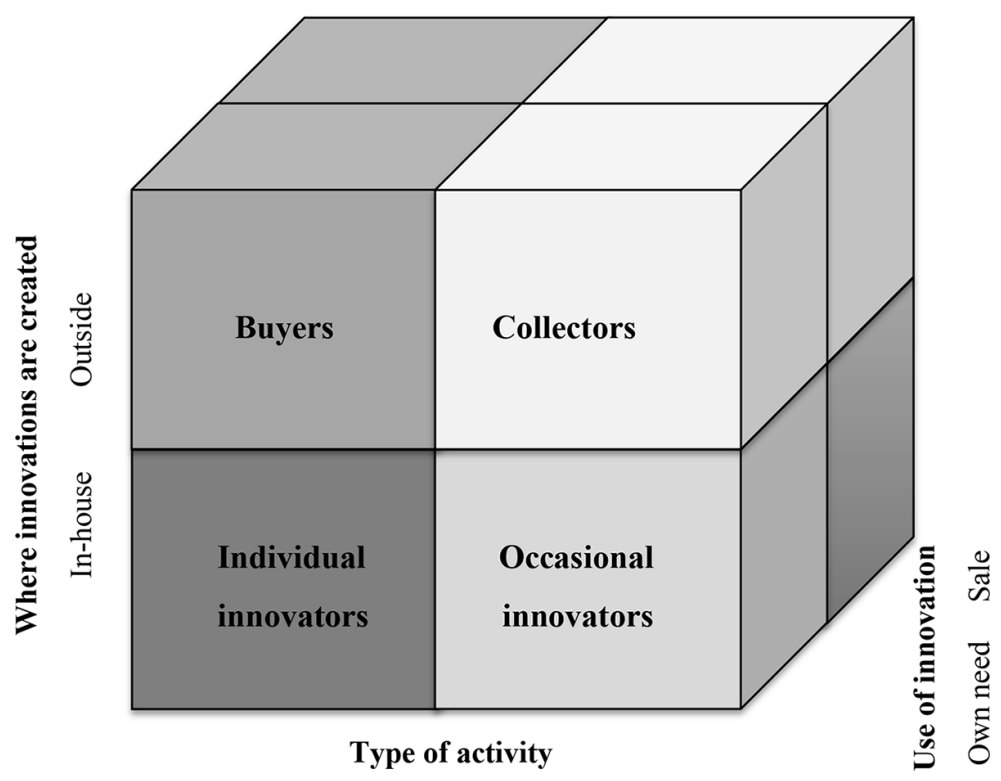

Continuous Occasional

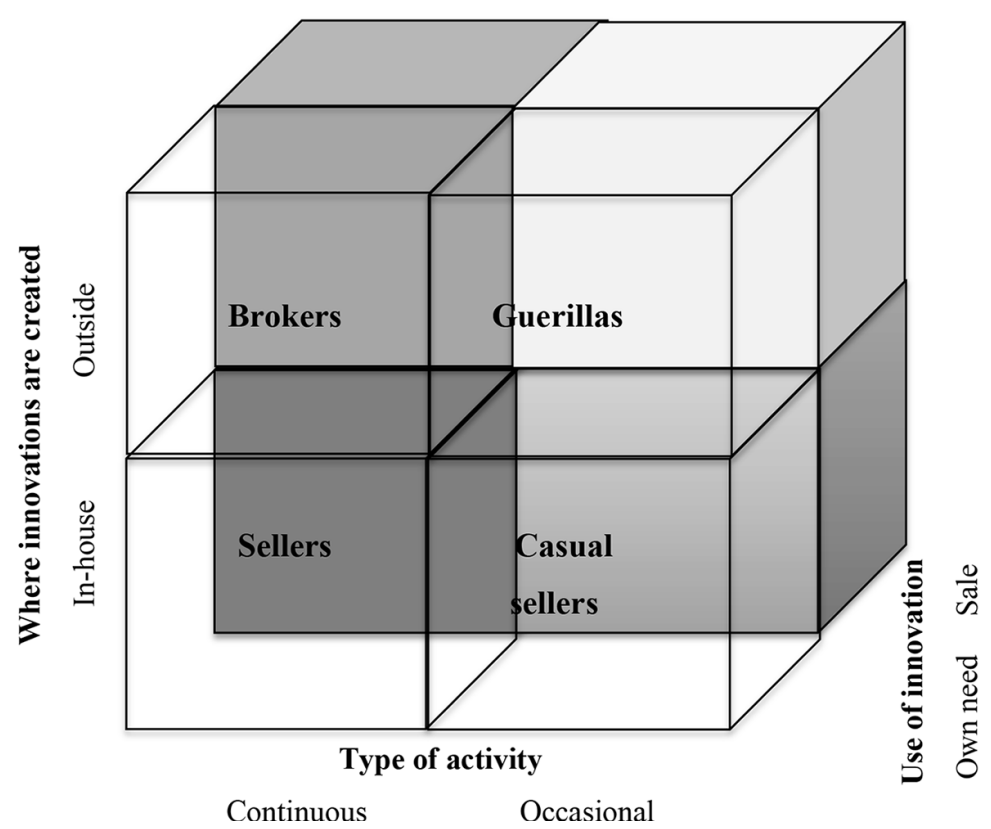

Fig. 1. Matrix of innovation strategy

Source: Cyfert, Mielcarek 2011, p. 22. 
especially those smaller and from traditional industries, create innovation on their own using their organization's resources and skills (GUS 2014, p. 86). This approach corresponds to the variant of individual or occasional innovator, as well as seller and occasional seller. However, Chesbrough (2006, p. 1) pointed out that high-tech industry companies that implement open innovation can adjust their business model and the process of innovation to the needs of the acquisition and processing of knowledge, and due to this adaptation it is possible to enhance the efficiency of an organization in creating innovations implemented in that organization or distributed in the market through commercialization.

The second dimension of the model is the type of activity in terms of its continuity. Constant activity enables a fast and flexible response to changes occurring in the environment and within the company (Penc 2001, p. 344). Business continuity favours control and coordination, as well as improving the process of innovation management (individual innovators, buyers, sellers or brokers). As a result, the conditions for synergies are created which contribute to raising the efficiency of its activities, In particular numerous advantages can be achieved by applying business process orientation (Harrington 1991, pp. 16-21), but the realization of constant innovative activity is costly and not always relates to the market demand and its competitive environment.

Thus a different approach is to focus on the implementation of breakthrough innovations that do not necessarily need to be based on continuous activity (Christensen, Raynor 2008). In the longer perspective only these innovators are able to build sustainable competitive advantage. The implementation of breakthrough innovation forces them to adapt the business model to the new operating conditions. Such a change, based on redesigning the current development path, is called the strategic renewal of businesses (Volberda, et al. 2001, p. 160). The third dimension is innovation's utilisation. Companies introducing innovations for their own use are seeking to improve their competitive position in two ways. First, it may be aimed at obtaining the leading position in the market through discounting innovator rent (buyers, individual innovators); second, to reduce the gap between the company and the market leader (collectors, sellers, occasional innovators, individual innovators) (Tidd, Bessant, Pavitt 2005, p. 121).

Sales of innovations as a strategy can also be carried out by several types of businesses model. For instance, large companies (including transnational corporations) with the introduction of new generation innovation may decide to sell older solutions to other markets where a product is in a growth phase of its life cycle (Bennett 1995, pp. 273-275). 
Table 1

Characteristics of innovation strategies

\begin{tabular}{|c|c|c|}
\hline $\begin{array}{c}\text { Strategy } \\
\text { type }\end{array}$ & Advantages & Disadvantages \\
\hline 1 & 2 & 3 \\
\hline Buyers & $\begin{array}{l}\text { Implementation of innovative projects } \\
\text { exceeding the capabilities of a single } \\
\text { company Reducing the level of costs by } \\
\text { separating R \& D activities } \\
\text { Building effective relationships with } \\
\text { partners } \\
\text { Possibility to build the company's image } \\
\text { thanks to the innovativeness of the } \\
\text { products and services } \\
\text { Reducing the level of risk Ensuring high } \\
\text { flexibility of the company's development }\end{array}$ & $\begin{array}{l}\text { Limiting the possibility of obtaining a } \\
\text { competitive advantage (imitation of } \\
\text { innovation) } \\
\text { Limiting the benefits resulting from the } \\
\text { development of the company's own } \\
\text { resources } \\
\text { Loss of control over the development } \\
\text { of innovative activities }\end{array}$ \\
\hline Collectors & $\begin{array}{l}\text { Implementation of innovative projects } \\
\text { exceeding the capabilities of a single } \\
\text { company } \\
\text { Ensuring flexibility in the selection of } \\
\text { partners } \\
\text { Cost reduction through outsourcing } \\
\text { Reducing the level of risk } \\
\text { Ensuring high flexibility of the company's } \\
\text { development }\end{array}$ & $\begin{array}{l}\text { Difficult adaptation to introduced } \\
\text { changes resulting from innovation lack } \\
\text { of procedures, appropriate organization } \\
\text { culture, etc. } \\
\text { Deterioration of conditions enabling } \\
\text { the synergy effect Limiting the benefits } \\
\text { resulting from the development of } \\
\text { company resources } \\
\text { Loss of control over the development } \\
\text { of innovative activities }\end{array}$ \\
\hline $\begin{array}{l}\text { Individual } \\
\text { innovators }\end{array}$ & $\begin{array}{l}\text { High probability of obtaining a competitive } \\
\text { advantage } \\
\text { Possibility to get an innovator's rent and } \\
\text { sales of developed innovations } \\
\text { Building the company's position on the } \\
\text { market } \\
\text { Possibility to improve the innovative activity } \\
\text { and development of the company's own } \\
\text { resources } \\
\text { Possibility to achieve a synergy effect } \\
\text { Ensuring high efficiency of innovative } \\
\text { activities }\end{array}$ & $\begin{array}{l}\text { Increase in operating costs } \\
\text { Limiting relationships with partners in } \\
\text { the field of innovation } \\
\text { The dependence of technology } \\
\text { developed within enterprise } \\
\text { Increase in the risk level of operations }\end{array}$ \\
\hline $\begin{array}{l}\text { Occasional } \\
\text { innovators }\end{array}$ & $\begin{array}{l}\text { Cost reduction in relation to the permanent } \\
\text { activity } \\
\text { Possibility of achieving an innovator's rent }\end{array}$ & $\begin{array}{l}\text { Limiting relationships with partners in } \\
\text { the field of innovation } \\
\text { Limited adaptation to introduced changes } \\
\text { resulting from innovation lack of } \\
\text { procedures, appropriate organization } \\
\text { culture, etc. } \\
\text { Deterioration of conditions enabling } \\
\text { the synergy effect } \\
\text { Increase in the risk level of operations } \\
\text { Limiting the effectiveness of } \\
\text { innovative activities }\end{array}$ \\
\hline
\end{tabular}




\begin{tabular}{|c|c|c|}
\hline 1 & 2 & 3 \\
\hline Guerrillas & $\begin{array}{l}\text { Lowering the level of risk } \\
\text { Cost reduction } \\
\text { Ensuring flexibility in the selection of } \\
\text { partners and projects } \\
\text { Possibility to influence the behaviour of } \\
\text { contractors }\end{array}$ & $\begin{array}{l}\text { No benefits resulting from the } \\
\text { development of the company's resources } \\
\text { There is no possibility of synergies } \\
\text { No possibility to gain a competitive } \\
\text { advantage thanks to innovations } \\
\text { Lack of development of the innovative } \\
\text { activity of the enterprise } \\
\text { Loss of the image of an innovative } \\
\text { company }\end{array}$ \\
\hline Brokers & $\begin{array}{l}\text { Lowering the level of risk Cost reduction } \\
\text { Building long lasting relationships with } \\
\text { partners } \\
\text { Possibility to influence the behaviour of } \\
\text { contractors } \\
\text { Access to knowledge and technology } \\
\text { resources }\end{array}$ & $\begin{array}{l}\text { No possibility to gain a competitive } \\
\text { advantage thanks to innovations } \\
\text { No benefits resulting from the develop- } \\
\text { ment of the company's resources } \\
\text { There is no development of the } \\
\text { innovative activity of the company } \\
\text { There is no possibility of synergies }\end{array}$ \\
\hline $\begin{array}{l}\text { Casual } \\
\text { sellers }\end{array}$ & $\begin{array}{l}\text { Cost reduction } \\
\text { Ensuring flexibility in conducting business, } \\
\text { including the selection of partners } \\
\text { Possibility of obtaining above average } \\
\text { profits from sales of developed innovations } \\
\text { (multiple sale of intellectual property / } \\
\text { technology: licences, patents) } \\
\text { The possibility of affecting the behaviour } \\
\text { of contractors }\end{array}$ & $\begin{array}{l}\text { Limiting the possibility of gaining a } \\
\text { competitive advantage thanks to } \\
\text { innovations } \\
\text { Limiting the possibility of the synergy } \\
\text { effect } \\
\text { Limiting the effectiveness of } \\
\text { innovative activities } \\
\text { Increased risk level }\end{array}$ \\
\hline Sellers & $\begin{array}{l}\text { Possibility of obtaining above average } \\
\text { profits from sales of developed innovations } \\
\text { Development of relationships with partners } \\
\text { Opportunity to improve innovative activity } \\
\text { and reduce its costs } \\
\text { Loss of competitive advantage resulting } \\
\text { from the disposal of innovation } \\
\text { Increase in the risk level of operations } \\
\text { The possibility of developing company's } \\
\text { own resources } \\
\text { Building the company's position on the } \\
\text { market thanks Possibility to create a } \\
\text { synergy effect } \\
\text { Possibility to influence the behaviour of } \\
\text { contractors }\end{array}$ & $\begin{array}{l}\text { Loss of competitive advantage } \\
\text { resulting from the disposal of } \\
\text { innovation } \\
\text { Increase in the risk level of operations } \\
\text { The possibility of developing } \\
\text { company's own resources } \\
\text { Building the company's position on the } \\
\text { market } \\
\text { Possibility to create a synergy effect } \\
\text { Possibility to influence the behaviour } \\
\text { of contractors } \\
\text { The need to constantly invest in } \\
\text { business development } \\
\text { High expenditure }\end{array}$ \\
\hline
\end{tabular}

Source: Mielcarek 2016, p. 114-116.

Another factor significantly influencing the way of utilizing innovation is the technological advancement of the industry. Adapting M. Porter's concept, it can be assumed that with increasing specialization of technology, 
the cost of entering a market increases. The start-up company is forced to purchase the innovations made by other entities, e.g. by the acquisition of patents or licences (buyer, collector variant).

\section{THE APPLIED RESEARCH METHOD}

\subsection{Data collecting procedure}

The presented data are the result of a procedure carried out on the basis of non-probability sampling on a group of medium and large Polish industrial companies belonging to sectors of low, medium and high technology. We conducted two phases of data collecting. The first one was a pilot study based on random selection and a mix of PAPI (paper-and-pencil interviewing) and CASI procedure (computer assisted self-interviewing). The second phase was complementary research based on the CATI method (computerassisted telephone interview). The CATI research was outsourced to a specialized company. The sampling procedure was based on the database of Polish innovative companies. The same questionnaire was used in both phases, and was directed to specialists or managers involved in innovation activity and R\&D. The study was based on a survey with a structured questionnaire consisting of 17 closed questions; details of the questionnaire are available in Mielcarek (2016).

In the first phase of research, out of the 600 questionnaires sent, 42 responses were obtained giving a feedback level of 6.7 percent, whilst from the other phase 50 more answers were collected. A total of 92 responses were obtained. However, due to the lack of completeness or errors in the questionnaires, 84 answers were finally accepted for further research.

\subsection{Characteristics of the study sample}

In particular, among the low-tech industry companies there were included those from "Clothing production and dyeing of fur" (12 responses obtained) and "Publishing; printing and reproduction of recorded media" (10 responses). For medium technology industries the research covered "Production of means of transport" (14 responses) and "Chemical industry" (24 responses) and for high-tech industry there were: "Pharmaceutical industry" (10 responses) and "Production of electronics and telecommunications" (14 responses). The study was conducted in 2015 , and the data cover the period 2012-2014. 


\subsection{The applied research method}

The research procedure covers an assessment of the effects of each innovation strategy variant based on the following selected criteria:

- the average innovation number as the total from the product, process, organizational and marketing innovations created in 2012-2014;

- the impact of generated innovation on achieved competitive advantage. Managerial ratings were based on a five-point scale: 1) innovation definitely did not affect the competitive advantage; 2) innovation did not affect much; 3) it is difficult to say whether innovations influenced the competitive advantage; 4) innovation contributed fairly and 5) innovation decisively influenced the competitive advantage;

- the most common indicated effect of innovation strategy from a selection of (managers could select multiple answers): entering new markets or increasing share in existing markets, increasing production capacity, increased production flexibility, reducing costs, building a brand, profit increase, meeting legal standards, gaining a competitive advantage, reducing the environmental impact.

To formulate the research result, several methods were applied. First of all, the main method used in the empirical part was logical reasoning based on deduction, induction and comparative analysis. In order to formulate reliable conclusions and research results, statistical methods were also used, in particular descriptive statistics of the sample (average, variability measures) and Pearson's correlation coefficient.

\section{EFFECTS OF INNOVATION STRATEGIES IN POLISH INDUSTRIAL ENTERPRISES - RESEARCH RESULTS}

Based on the results of the conducted study of Polish industrial enterprises in 2012-2014, on average there were eight innovations created and they somewhat contributed to gain competitive advantage by a company -4.260 in the five-point scale (see Table 2 and Figure 2). Analysing the utilisation of innovation strategies, the first observation is that for the eight distinguished variants only six are actually used in Polish industrial enterprises. There is a lack of representation of brokers and buyers.

The most commonly occurring type of innovation strategy is individual innovator (34.8 percent of the test sample), which is based on continuous activity, company's resources and the effects of activities are discounted by organization. It is also a strategy that provides the highest impact of created 
innovation on the achieved competitive advantage of a company (4.625 innovation decisively influenced the competitive advantage) and the aboveaverage number of created innovations (nine in comparison to the average of eight innovations within the test sample). The goal of this particular strategy, and in general the most commonly occurring, is to "enter new markets or increases the share in existing markets". The next objectives of innovation strategies in the test sample were "reducing cost" and "gaining competitive advantage".

Table 2

Indicators of innovation strategies of Polish industrial enterprises in 2012-2014 ( $\mathrm{n}=92)$

\begin{tabular}{|c|c|c|c|c|c|}
\hline $\begin{array}{l}\text { Strategy } \\
\text { type }\end{array}$ & $\begin{array}{c}\text { Population } \\
\text { share }\end{array}$ & $\begin{array}{c}\text { Most } \\
\text { represented } \\
\text { industry }\end{array}$ & $\begin{array}{l}\text { Impact on } \\
\text { competitive } \\
\text { advantage }\end{array}$ & $\begin{array}{c}\text { Average } \\
\text { number of } \\
\text { innovation }\end{array}$ & $\begin{array}{l}\text { Main effect } \\
\text { of innovation } \\
\text { activity }\end{array}$ \\
\hline $\begin{array}{l}\text { Individual } \\
\text { innovators }\end{array}$ & $34.8 \%$ & $\begin{array}{l}\text { Production of } \\
\text { means of transport }\end{array}$ & 4.625 & 9 & $\begin{array}{l}\text { Enter new } \\
\text { markets or } \\
\text { increase share in } \\
\text { existing markets }\end{array}$ \\
\hline Sellers & $28.3 \%$ & Chemical industry & 4.461 & 5 & $\begin{array}{l}\text { Enter new } \\
\text { markets or } \\
\text { increase share in } \\
\text { existing markets }\end{array}$ \\
\hline $\begin{array}{l}\text { Occasional } \\
\text { innovators }\end{array}$ & $17.4 \%$ & Chemical industry & 3.875 & 17 & $\begin{array}{l}\text { Reducing costs. } \\
\text { Enter new } \\
\text { markets or } \\
\text { increase share in } \\
\text { existing markets }\end{array}$ \\
\hline $\begin{array}{l}\text { Casual } \\
\text { sellers }\end{array}$ & $14.1 \%$ & $\begin{array}{l}\text { Pharmaceutical } \\
\text { industry }\end{array}$ & 3.692 & 3 & $\begin{array}{l}\text { Enter new } \\
\text { markets or } \\
\text { increase share in } \\
\text { existing markets }\end{array}$ \\
\hline Guerrillas & $3.3 \%$ & $\begin{array}{l}\text { Production of } \\
\text { electronics and } \\
\text { telecommunications }\end{array}$ & 3.000 & 1 & $\begin{array}{l}\text { Gaining a } \\
\text { competitive } \\
\text { advantage }\end{array}$ \\
\hline Collectors & $2.2 \%$ & $\begin{array}{l}\text { Production of } \\
\text { electronics and } \\
\text { telecommu- } \\
\text { nications }\end{array}$ & 4.500 & 1 & $\begin{array}{l}\text { Building a brand. } \\
\text { Enter new } \\
\text { markets or } \\
\text { increase share in } \\
\text { existing markets }\end{array}$ \\
\hline
\end{tabular}

Note: Bold font indicates values above average of the test sample

Source: own work based on research results. 
When analysing the presented data by the criterion of the number created innovations, the most successful strategies are those focusing on the organization's resources and their own usage (individual innovator and occasional innovator). According to the Central Statistical Office of Poland, only 33.8 percent of Polish industrial enterprises and 27.3 percent of service companies cooperated in 2011-2012 with other actors in the field of innovative activity (GUS 2014, p. 86). Other research also confirms that most companies produce innovations based on their own resources and a significant proportion of the innovations' outcome take the form of changes introduced in or used by the organization, which should be identified with the approach of closed innovation. In the concept of closed innovation, companies focus on the organization of research and development activities based on their own resources, which foster an attempt to build the broadest possible knowledge base, increase the efficiency of innovative projects and build an appropriate protection of the developed intellectual property (Mielcarek 2016). It is assumed that through the consistent and systematic development of a company's resources, it increases their competitive advantage, reduces the business risk and creates barriers preventing prospective competitors from entering the industry (Chesbrough 2004, p. 23).

Assessing innovation strategies by criterion of industry type, the variant with the highest impact on competitive advantage is the individual innovator which is most broadly represented in "Production of means of transport", i.e. medium technology industry. As an additional cross-section analysis, below there is a ranking of industry branch in view of the influence of innovations on creating competitive advantage. The highest result is for "Production of means of transport" 4.43, "Publishing; printing and reproduction of recorded media" 4.27, "Chemical industry" 4.25, "Pharmaceutical industry" 4.2, "Production of electronics and telecommunications" 4.21, "Clothing production and dyeing of fur" 4.08. Based on the above data, it must be emphasized that there is a relatively low dispersion of this variable and all results fit in the range of "innovation contributed fairly to competitive advantage". Between the highest and the lowest result there is only a distance equal 0.35 on the five-point scale. It is also worth pointing out that although the differences between each industry are rather small, the achieved competitive advantage of high-tech industry is the lowest from all the branches in the test sample. 
Competitive advantage

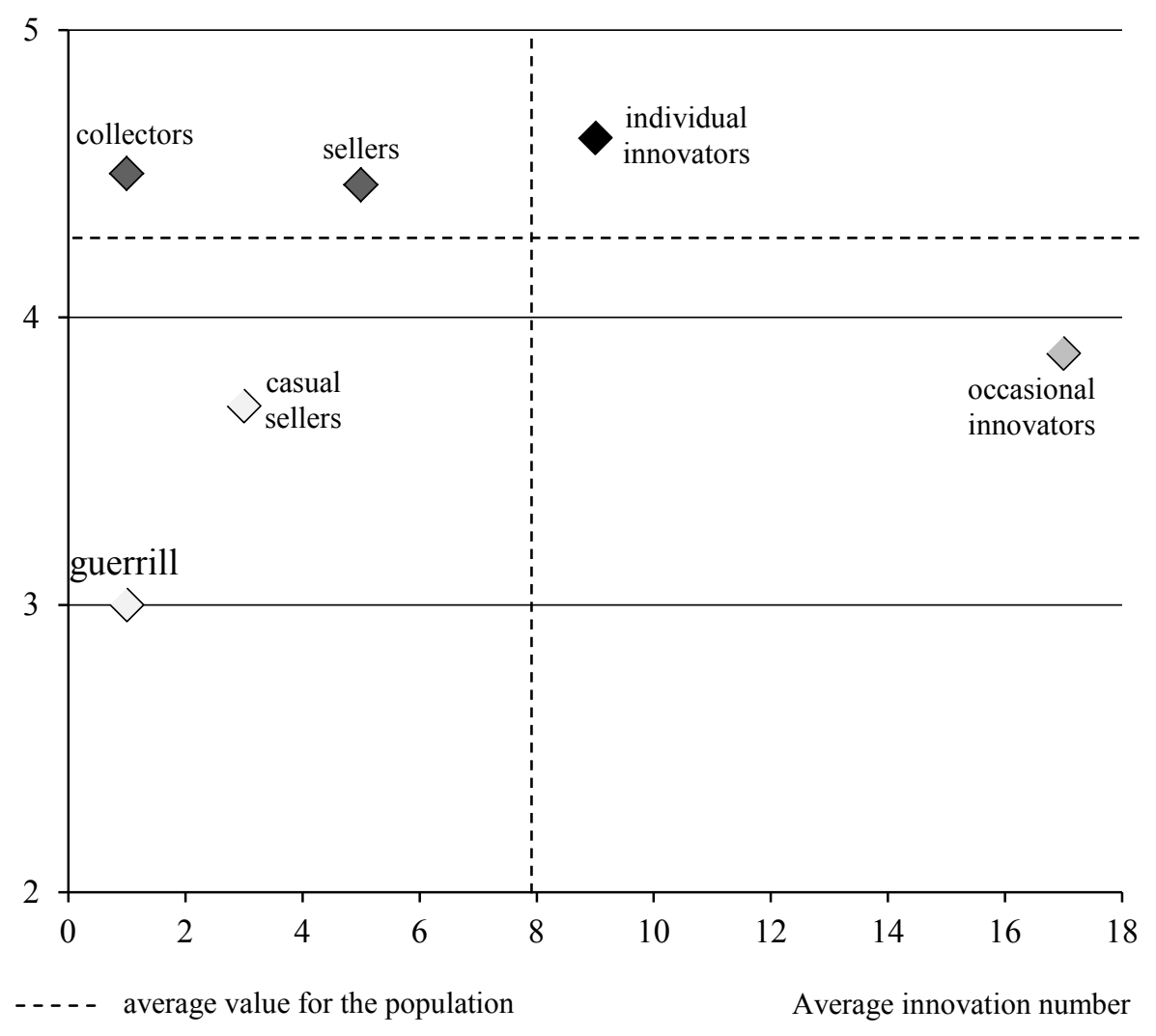

Fig. 2. Effects of innovation strategies of Polish industrial enterprises in 2012-2014

Source: own work based on research results.

However, the most fundamental conclusion from the above presented data is the lack of correlation between achieved competitive advantage and number of created innovation (correlation coefficient 0.1795). This phenomenon seems to deny the commonly prevailing view of relationship based on feedback: the more innovations created, the higher the achieved competitive advantage. This reluctance to raise number of innovation projects to gain competitive advantage can be called an innovation funnel paradox. In the development funnel concept presented by Wheelwright and Clark (1992), innovation activity is treated as a process composed of stages 
of problem-solving gates. The advancement of each project, from the initial phase of development finalization to its implementation, depends on the positive assessment on each of its stages. As a result, the accepted projects are selected based on the applied criteria in order to reduce uncertainty. By assumption, this approach allows to achieve the balance, between reducing the cost of projects that eventually will not be finalized, and the negative effect of losing growth potential due to the early closing of projects.

By adopting this concept to explain the innovation funnel paradox, several more variables and factors should be analysed. The lower number of created innovations, at the same time ensuring an increase of competitive advantage, can be the result of the greater maturity of the organization. This means that the concepts of innovation at the stage of the projects' portfolio management are more precisely evaluated and, due to the fewer number of accepted ideas, implemented with the greater involvement of the organization's resources.

At the same time the company, due to reaching a certain stage of development and market embeddedness, outdistances its main competitors, who affect less pressure for further investment and development. If external conditions are stable for a sufficiently long time (level of competition, customer demand, and technology changes) a company can enter into a phase of excessive institutionalization of the innovation system. The institutionalization of the innovation system is interpreted as all actions of management aimed at building the readiness and maturity of the organization's innovation system (creating organizational units, rules and procedures and the improvement of the innovation system's components). However, according to the research this can translate into a negative effect that shifts organizational effort, and instead of growth it can focus on sustaining and improving the innovation system itself (Mainiero 1994).

\section{CONCLUSIONS}

The main purpose of this article was to assess the effects of innovation strategies applied in Polish industrial enterprises. This procedure concerns the verification of innovation strategies defined by a model consisting of three simultaneously imposed criteria: the place of innovation's creation, the type of activity in terms of continuity, and the innovation's utilisation. As a result eight different variants of innovation strategy were created and empirically tested. 
Based on the conducted research procedure, the main results are formulated in the following key findings:

1. Not all the defined variants of innovation strategies were represented in Polish industrial enterprises; there is a lack of brokers and buyers.

2. Individual innovator is the type of strategy with the highest impact of innovation on achieved competitive advantage and the above-average number of created innovation.

3. According to the number of created innovations, the most successful strategies are those focusing on the utilisation of the organization's resources and their own usage (individual innovator and occasional innovator), which confirms the results of other research.

4. In the case of the relation of industry type and achieved competitive advantage due to innovation strategy, there is a very low dispersion of values within the test sample (only 0.35 on the five-point scale), which means the lack, or relatively low, dependency of those variables.

5. Finally the most important finding, from the overall perspective, is the very low correlation between the number of the created innovations and the achieved competitive advantage (correlation coefficient 0.18 ). This phenomenon was called the innovation funnel paradox and can have different origins. The group of external causes covers lowering the pressure from customers and competitors on introducing innovation, especially when reaching the mature phase of development of the industry, or due to the stabilization of the environment (in the economic, technological, social and demographic sphere). This paradox might be also caused by 20 internal conditions which are achieving a high level of organization maturity that contributes to a more precise selection of innovation projects and greater resource engagement into the accepted ones. By applying a more critical perspective we can point out some negative effects referring to the excessive institutionalization of the innovation system, such as increasing inertia, risk aversion and bureaucracy that can reduce the number of created innovations.

On the basis of the above-mentioned conclusions, it cannot be finally discounted that a strategy based on less innovation can get better results, therefore the phenomenon of the innovation funnel paradox should be subjected to further analysis, especially in the aspect of the development path dynamics of individual organizations. 


\section{REFERENCES}

Beers, C., Zand, F., R\&D cooperation, partner diversity, and innovation performance: An empirical analysis, "Journal of Product Innovation Management", 31 (2), pp. 292-312, 2014.

Bennett, R., International Marketing. Strategy, Planning, Market Entry \& Implementation. Kogan Page, London 1995.

Bower, J. L., Christensen, C. M., Disruptive technologies: catching the wave, "Harvard Business Review", 73 (1), pp. 506-520, 1995.

Chesbrough, H. W., Managing open innovation, "Research Technology Management”, 47 (1), pp. 1-36, 2004.

Chesbrough, H. W., Crowther, A. K., Beyond high-tech: Early adopters of Open Innovation in other industries, "R\&D Management", 36 (3), 2006, pp. 229-236.

Christensen, C. M., Raynor, M. E., Innowacje. Napęd wzrostu [Innovations. Growth Devise]. Studio Emka, Warszawa 2008.

Cyfert, S., Mielcarek, P., Modele realizacji działalności innowacyjnej przedsiębiorstwa [Models of realizing the innovative activity of the company] „Przegląd Organizacji”, 4, pp. 20-23, 2011.

Drucker, P., Natchnienie $i$ fart, czyli innowacja i przedsiębiorczość [Innovation and Entrepreneurship]. Studio Emka, Warszawa 2004.

Dodgson, M., Technology Strategy and the Firm: Management and Public Policy. Harlow, Longman 1989.

Ezzia’, F., Jarboui, A., Does innovation strategy affect financial, social and environmental performance?, "Journal of Economics, Finance and Administrative Science", 21, pp. 14-24, 2016.

GUS, Działalność innowacyjna przedsiębiorstw w latach 2011-2012, Informacje i Opracowania Statystyczne [Innovative activities of enterprises in the years 2011-2012, Information and Statistical Studies], Warszawa 2014.

Hammer, M., Champy, J., Reengineering the Corporation. A Manifesto for Business Revolution. Harper Business, New York 1993.

Harrington, H. J., Business Process Improvement. The Breakthrough Strategy for Total Quality, Productivity and Competitiveness. McGraw-Hill, New York, 1991.

Kaplan, R. S., Norton, D. P., Putting the Balanced Scorecard to Work, "Harvard Business Review", pp. 134-147, September-October, 1993.

Karlsson, Ch., Tavassoli S., Innovation strategies of firms: what strategies and why?, "Journal of Technology Transfer", 41 (6), pp. 1483-1506, 2016.

Laursen, K., Salter, A. J., Open for innovation: The role of openness in explaining innovation performance among U.K. manufacturing firms, "Strategic Management Journal", 27 (2), pp. 131-150, 2006.

Mainiero, L., Corporate renewal: Evolutionary or leader driven?, "Academy of Management Executive", 8 (1), pp. 83-84, 1994.

Materia, V. C., Pascucci, S., Dries, L., Are In-House and Outsourcing Innovation Strategies Correlated? Evidence from the European Agri-Food Sector, "Journal of Agricultural Economics", 68 (1), pp. 249-268, 2017. 
Mielcarek, P., Development of Innovation Process in an Open Innovation Model - an IT Case Study, "Przegląd Organizacji", 6, pp. 33-41, 2015.

Mielcarek, P., Procesy zarzadzania innowacjami $w$ przedsiębiorstwach przemystowych [Innovation management processes in industrial enterprises]. Difin, Warszawa 2016.

Niemczyk, J., Uktady outsourcingowe w ujęciu procesowym [Outsourcing in a business process approach] [in:] Romanowska, M., Trocki, M. (eds.) Podejście procesowe $w$ zarzadzaniu [Business proces approach to management]. SGH, Warszawa 2004.

Pomykalski, A., Zarzadzanie innowacjami. [Innovations management]. PWN, WarszawaŁódź 2001.

Tavassoli, S., Determinants and effects of innovation: context matters [in:] Doctoral dissertation in the Blekinge Institute of Technology, Faculty of Engineering, Department of Industrial Economics, 2014.

Teece, D. J., Dynamic Capabilities and Strategic Management. Oxford University Press, Oxford 2009.

Tidd, J., Bessant, J., Pavitt, K., Managing innovation. Integrating technological, market and organizational change. John Wiley \& Sons, Chichester 2005.

Wheelwright, S. C., Clark, K. B., Revolutionizing Product Development: Quantum Leaps in Speed, Efficiency, and Quality. The Free Press, New York 1992.

Whittington, R., What is Strategy and does it Matter? Routledge, London 1994.

Volberda, H. W., Baden-Fuller, C., Bosch, F. A. J., Mastering strategic renewal: mobilizing renewal journeys in multi-unit firms, "Long Range Planning", 34, 2001.

Received: August 2016, revised: May 2018

Acknowledgement: This research paper was funded by a scientific grant awarded by the National Science Center, Poland as part of the project UMO-2016/21 / D / HS4 / 00696 entitled "Improving the processes of open innovation and strategic renewal of the enterprise" headed by Dr. Pawet Mielcarek. 